American Journal of Applied Sciences 9 (1): 24-31, 2012

ISSN 1546-9239

(C) 2012 Science Publications

\title{
Ethics and Sustainability: A Review of Water Policy and Management
}

\author{
${ }^{1}$ Ravichandran Moorthy and ${ }^{2}$ Ganesan Jeyabalan \\ ${ }^{1}$ School of History, Politics and Strategy, Faculty of Social Sciences and Humanities, \\ University Kebangsaan Malaysia, 43000 Bangi, Selangor, Malaysia \\ ${ }^{2}$ Ministry of Science, Technology and Innovation, Putrajaya, Malaysia
}

\begin{abstract}
Problem statement: This is a review paper that examines the extent aspects such as ethics, sustainability and the environment manifest in the water policy and water management in Malaysia. The study examines two aspects of this topic; firstly it examines the various objectives and considerations in the National Water Policy and secondly it discusses the issues that arise regarding water policy and management, especially with regard to federal-states jurisdiction issues, legislations in water management and the problems related to inter-agency coordination, especially among agencies involved in the management of rivers. Approach: A qualitative approach is employed in this study. It provides a comprehensive review of the stated problem based on document analysis and interviews with individuals involved in policy formulation and from agencies involved in water management. Results: The study reveals two major findings; the first shows that the National Water Policy provide a holistic approach in dealing with water-by providing safe, adequate and affordable water supply to people; providing sufficient water that will ensure national and food security and promote rural development; sufficient water to spur and sustain economic growth; and protection of the water environment to preserve water resources. Second, it examines issues regarding water management such as the jurisdiction between federal and state governments, legislations and enforcement and inefficiency in inter-agency coordination that hinder the realization of this policy's objectives. Conclusion: The study concludes that despite the holistic coverage of the national water policy, there are apparent problems with regard to the jurisdiction, legislation and coordination initiatives that have resulted in the poor management of water resources. The study postulates that, in addition to better coordination between water related agencies and more cohesive water legislations structure, it is fundamental to infuse the knowledge of 'water ethics' among water managers, institutions, the general public and into water policy formulation and implementation initiatives.
\end{abstract}

Key words: National Department of Environment (DOE), water legislation, water ethics, inter-agency coordination, river pollution, practices regarding water resources, coordination initiatives, environmental ethics

\section{INTRODUCTION}

Malaysia is well endowed with abundance of natural water resources, which has significantly contributed to the socio-economic development of the country. However, the situation has somewhat changed over the last decade, from one of relative abundance to one of scarcity. The drastic rise in the demand for water due to growth in population, urban development, industrialisation and the increase of irrigated agriculture have placed additional pressure on the water resources of the country, in addition to contributing to the increase in water pollution. Many environmental experts and ethicists have warned against the dire consequences to humans and ecosystems should the quality of water in its sources continue to deplete. Some have even argued that the way towards sustainability of water resources is to slow the pace of development to a level that is within the carrying capacity of the river basins. The National Water Policy of the country is designed to manage the quantity, quality and reliability of the nation's water resources, in order to achieve optimum, long-term, environmentally sustainable, social and economic benefits for society from their use

Corresponding Author: Ravichandran Moorthy, Politics and Strategy, Faculty of Social Sciences and Humanities, University Kebangsaan Malaysia, 43000 Bangi, Selangor, Malaysia 
(Yew, 2004). The main aim of this policy is to bring about change in behaviour regarding the use of waterwhich is based on the realization that the only reliable route towards water sufficiency is by 'changing the habits' of water use. As such, water policy may eventually influence the public and private decision making process towards water conservation.

In view of the fact that water is vital to the sustainability of life and the ecosystems on this planet, it becomes imperative to embrace 'water ethics' in policies and practices regarding water resources management. Water ethics should be looked at from the perspective of environmental ethics that affords an ideational setting to understand the 'ethical management' of water resources. Although environmental ethics is relatively a new concept compared to social ethics-it offers moral and ethical justifications for a social redress of water issues. Water ethics comprise all aspects of water use-access, utilization, allocation, quality, protection and other aspects of water management. Therefore 'ethical precepts' can support the decision options in issues "involving a range of scientific domains (hydrology, groundwater, precipitation and runoff, water quality) and requires simultaneous consideration from different areas of water use, both from the supply and demand side (an integrated approach to water resource management) and their integration with socioeconomic aspects (Refsgaard, 2002) Even if the tools and methodologies of the water sector are often technical, the emerging issues are not "restricted to technical problems as they are also challenged by procedural items associated with stakeholder participation, especially at the level of communication with water managers and decision makers (Refsgaard, 2002).

Based on the discussion above, this study examines the extent aspects such as ethics, sustainability and the environment manifest in the water policy dimensions and water management in Malaysia. More specifically, two aspects of this subject are scrutinized; firstly it examines the various objectives and considerations in the National Water Policy and secondly it discusses the issues that arise regarding water policy and management, especially with regard to federal-states jurisdictions issues, legislations in water management and problems related to inter-agency coordination, especially among agencies involved in the management of rivers. In addition to problem-based perspective, the study also employs an ethical framework in analysis. Such framework provides for the deliberation of ethical precepts, especially on how to balance different benefits, risk and duties when dealing with environmental issues. Essentially, it is not about seeking a singular correct solution to an ethical issue but rather it suggests different choices made after ethical reflections (Macer, 2008; Moorthy and Sivapalan, 2010; Gandaseca et al., 2011, Moorthy and Jeyabalan, 2011).

\section{MATERIALS AND METHODS}

This study reviews the literature from various sources, especially from published water policy statements, government white paper, scientific reports by relevant agencies, book and journals and related documents on water policy and river water management in Malaysia. The researcher made a comprehensive search of the subject matter corpus by using electronic and non-electronic databases. The study also employed expert interview method to solicit feedback from several individuals involved in policy formulation and from agencies involved in river management.

\section{RESULTS AND DISCUSSION}

The review and discussion on water policy dimensions and water management is divided into three parts. The first part examines the various objectives and considerations in the National Water Policy. The second part examines legislation issues regarding federal-states jurisdictions and the third part discusses issues pertaining to inter-agency coordination.

National water policy: The National Water Policy is formulated to support the nations 'Vision 2020', which is the aspiration to achieve developed nation status by the year 2020. The objective is for Malaysia to be able to conserve and manage its water resources, as to ensure adequate and safe water for its citizens and the ecosystems. The policy has outlined several key objectives. This first objective is 'water for people' which means that all people should have access to safe, adequate and affordable water supply. Second is 'water for food and rural development', which refers to the provision of sufficient water that will ensure national food security and promote rural development. The third objective is 'water for economic growth'-provision of sufficient water to spur and sustain economic growth within the context of knowledge based economy and ecommerce. The fourth is 'water for environment', which promotes the protection and preservation of water resources (both surface and groundwater resources) and natural flow regimes, biodiversity and cultural heritage as well as the mitigation of water related hazards. The National Water Policy emphasizes that the way forward to a prosperous and sustainable 
future is by keeping development to a level that is within the carrying capacity of the river while protecting and restoring the environment.

In the formulation of this policy, several driving forces were envisioned and identified that were expected to have an impact on the national water resources, especially in the first quarter of this century. Such forces were expected to manifest from the transformation in population demography, socioeconomic changes, environmental demands, technological progress and from improvements in the governance of water resources. In terms of demography, the rapid growth in population, increased urbanization and altered migration and mobility patterns, will have significant implications on water resources. The impacts will include augmented demand for municipal water supply, demand for water for irrigation as a result of increased demand to produce more food, the encroachment of industries into once agriculture land and pollution caused by urbanization, industrialization and agricultural wastewater discharges that put enormous stress on the quality of water resources. Socially, capitalist lifestyles and consumption patterns have contributed to overuse and wasteful use of water. Rapid industrialization as a result of market-economic activities has increased the demand for water for industrial use and has also aggravated pollution in the water sources-especially rivers due to industrial effluents. Another important driving force regarding water resource management is the advent of environmental issues that impact on both the human existence and the eco-systems. Environmental degradation as the result of climate change, exploitation of water resources (both surface and groundwater) and the effects of pollution to the quality of water has simultaneously produced grave consequences to the health of aquatic and its interdependent eco-systems.

However, there has been increased awareness and concerns among the populace over environmental degradation. Such awareness can be useful in the push for more effective natural resources policy considerations and implementation. The discourse for a suitable water policy is also mindful to the opportunities that scientific research and technology can offer to the effective conservation and management of water resources. Technology can be employed to improve 'efficient water use', improve water distribution, reduce pollution and perhaps assist in "the selection of drought-, pest- and salt-resistant crops" (Ti and Facon, 2001) that may reduce water use. In addition, it can contribute towards improving water reuse and water-recycling technologies and explore the use of renewable energies in water management and conservation initiatives. Another consideration is the aspect of governance of water resources from the institutions, legal reforms and stakeholder participation perspectives-especially in the decision-making process. "This will also include the shift from water supply management to water demand management and the management of water resources within the carrying capacity of the river basins" (Ti and Facon, 2001).

The water policy consideration in Malaysia also proposes for a set of initiatives to be developed in order to achieve the objectives of the vision. These initiatives can be translated into four challenges towards securing a sustainable water future for the nation. These challenges are outlined in Table 1

Issues in water policy and management: The discussion is divided into three parts, namely federalstates jurisdictions issues, legislations regarding water management and problems related to inter-agency coordination in river water management.

Federal-states jurisdictions: Environmental management and conservation in Malaysia are implemented within the context of sustainable development, which embodies three pillars; economic development, social development and environmental protection. In order for sustainable development to be achieved, the strength of all three pillars must be ensured and reinforced. Therefore, the National Policy related to the environment incorporates the essence of these three pillars. According to this policy, integrated and effective cooperation and coordination among government sectors and between government and other sectors shall be enhanced in order to achieve efficient environmental management and protection. Moreover, it underlines that the management and technical capabilities of federal and state governments and local authorities on environmental matters shall be strengthened to provide for effective implementation of environmental laws and regulations.

Constitutionally, water has been under the State's jurisdiction and the role of the Federal Government regarding water matters was limited. The jurisdiction and legislative powers in all aspects of water are distributed between Federal and State Governments in accordance with the Legislative Lists of the Federal Constitution. These are the Federal, State and Concurrent Lists. 
Am. J. Applied Sci., 9 (1): 24-31, 2012

Table 1: Challenges for sustainable water resources

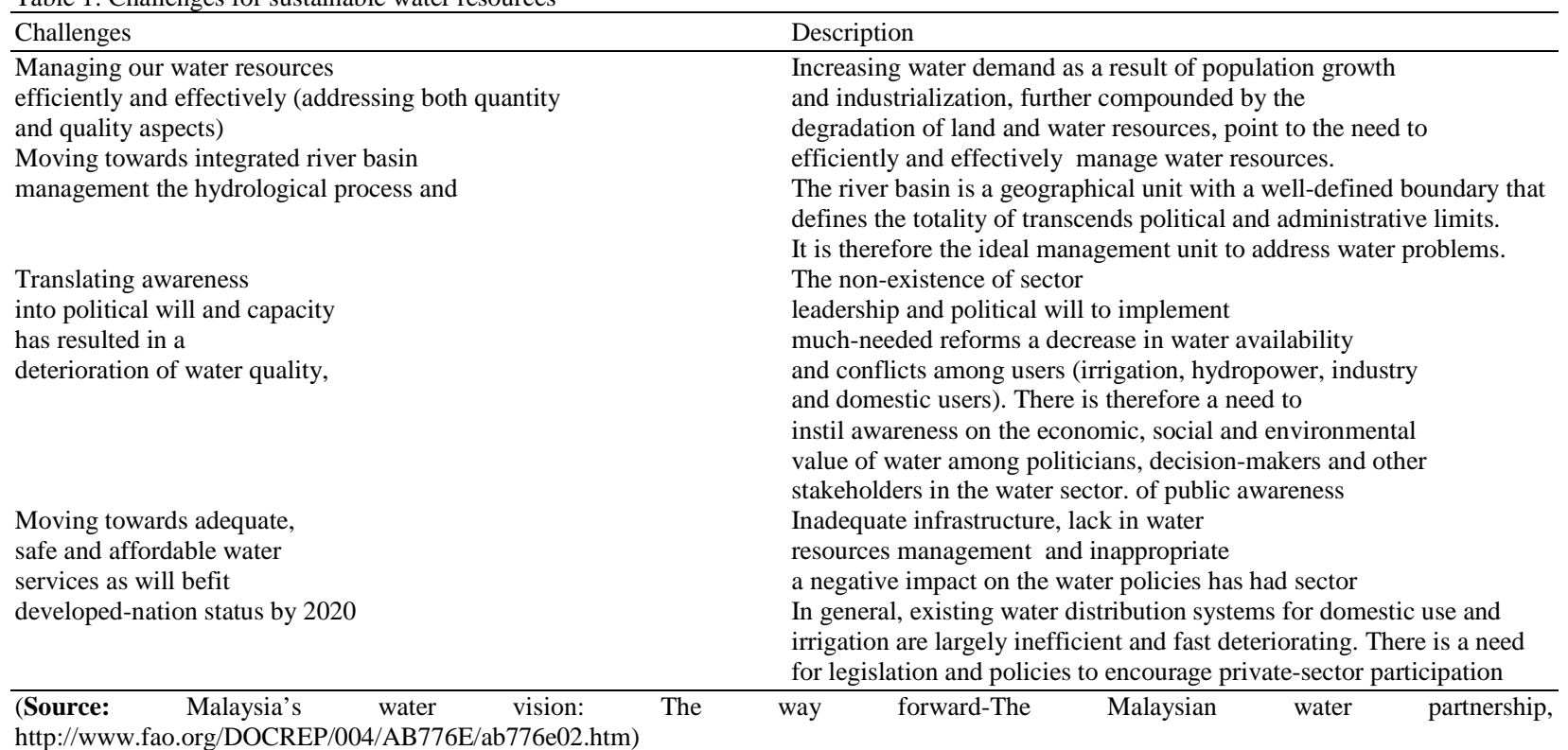
http://www.fao.org/DOCREP/004/AB776E/ab776e02.htm)

It is often remarked that 'water' is essentially a State matter. State's jurisdiction over water matters includes rivers, lakes, streams and water beneath the surface of the land. Although the state has primacy over matters of water, the Federal Government also possess specific powers, for example, over federal works including water supplies, rivers and canals except for those which are wholly within one State or are regulated by an agreement between the States concerned. The Parliament may make laws with respect to any matter in the State list for the purpose of promoting uniformity of the laws of two or more States. However, if it concerns the restriction of the right of the State to use any river wholly within that State, approval has to be obtained from the State Legislature before it can become effective (Lee, 2004).

Nevertheless, the situation changed since January 2005 when the Federal Constitution was amended to allow for joint responsibility in water between states in Peninsular Malaysia and the Federal Government (Shahabudin, 2005). The management of water resources is now more clearly divided between the State and the Federal governments. The governance of the water sector is now divided between Ministry of Energy, Communication and Water (in charge of water development and services) and Ministry of Natural Resources and Environment (in charge of water as a resource). Therefore, the Federal Government will only concentrate on policy matters and by setting policy directions while the States will manage the existing river basins with the view of protecting the quality of raw water and identifying new water basins when necessary. According to Lee (2004), there are some 30 Federal laws related to land and water and another three or four enactments in each state. Although plentiful in numbers, these legislations generally govern the use water rather than the protection of water resources. They are fragmented and often disjointed, only adequate to serve the sectoral management needs - a situation that has led to conflicts and overlaps of water issues. Several states namely the State of Selangor, Sabah and Sarawak have moved to legislate their own water resources, for example in April 1999, the State of Selangor has passed as enactment that provides for the formation of the Selangor Water Management Authority. At present, there is no single authority assigned with the responsibility for overall planning and management of water resources in the country. The numerous water management agencies at both states and federal levels often have overlapping roles and gaps in certain functions. This situation has been further exacerbated by insufficient coordination among agencies with regard to meeting national objectives.

There were cases in several states that ineffective regulatory structures and poor enforcement have led to inefficiency in the operating systems. The management of water resources involves numerous departments and agencies, which operate independently of one another according to the specific responsibilities assigned to them. Since there are numerous laws with gaps and overlaps and many agencies and departments involved in dealing with fragmented sectoral functions, 
enforcement initiative with regard to water resources has become futile and inefficient. The management of water resources in the country involves a number of Federal, State departments and agencies that operate dependently or independently of one another according to the specific tasks assigned to them. Along with it, matters related to environmental management and pollution control are also dispersed among Federal, State and Concurrent Lists in the Constitution. Such situation has contributed to the poor management of water resources in the country. In April 2009, the Malaysian government set up a new ministry called Ministry of Energy, Green Technology and Wateramong others to restructure the national water exercise as problems arise with the federal government's over control of state's water assets and with the companies that supply water to the state of Selangor and the federal territories of Kuala Lumpur and Putrajaya. In Malaysia, with the changing political climate since 2007, water matters have been heavily politicized between the Federal and State governments-which some may seriously question the lack of ethics and social justice in these debates.

Water legislations: There are several environmentallyrelated legislations both at the Federal and State levels for the control of environmental pollution or management of the environment. The Environmental Quality Act 1974 (EQA) is one of the key legislation enacted to prevent pollution. The EQA, which came into effect on 15 April 1974, were formulated to prevention, abatement, control of pollution and also enhancement of the environment. To supplement the EQA, several other regulations were gazetted to provide additional safe guards to water sources. These regulations also refer to river water management. Table 2 illustrates these legislations and regulations.

The Water Act 1920 is one of the oldest pieces of legislation in existence regarding water. The law was enacted during colonial times and was revised in 1989. Since 1971, the Water Enactments of some States were amended to include prohibition of pollution of river water. The law however only applies to the Federate Malay States (Negeri Sembilan, Pahang, Perak and Selangor) and Malacca, Penang and the Federal Territory. In the state of Selangor, the Act has been repealed and replaced with the Selangor Water Management Authority Enactment 1999. This Water Act provides the control of rivers within the State's boundaries to the government of the State. The Act prohibits certain activities affecting rivers such as diversion of water from rivers, pollution of rivers and damage of river banks. The agency responsible for implementing the provisions of the Act is the District Office, which has serious limitations on its enforcement capabilities. It is doubtful that this act has been effectively enforced given the state of the rivers in the country.

When Malaysian obtained independence in 1957, the new Federal Constitution (through Schedule 9) has placed all works in water supply, river and canals, control of silt, riparian rights as within State jurisdiction. The State has supreme ownership of all the rivers within the restrictions of the state, whereas water supply, rivers and canals shared by more than one State are under Federal proficiency. Subsequently, in 1960, the government enacted the Land Conservation Act 1960, which was aimed to consolidate the law relating to conservation of hill and the protection of soil from erosion and the inroad of silt. The Act was made pursuant to Article 76(3) of the Constitution, which requires the Act to be adopted by the States before it becomes operational. Hill lands needs to be gazette and once this is done there is strict prohibition of land clearing of hill lands except with permit. The State Land Office which is responsible for implementing the Act has the powers to prohibit the removal of trees or order the laying of drains or water courses to prevent erosion. Although this Act was endowed with certain power of enforcement, it is doubtful whether it has been effectively enforced-as there were very few hill lands gazetted and more recent trends indicated that even gazetted forest reserves on hills have been revoked for development. It is also doubtful whether the provisions of this Act were properly monitored and enforced due to constraints in adequate personnel and resources in the Land Office. In 1965 the National Land Code was enacted-aimed at consolidating all laws pertaining to land and land tenure and for the purposes of achieving uniformity of law in all the States of the Peninsular. The Act also includes river (which includes rivers, stream or artificial deviations). With this Act, several States have gazetted river reserves.

The most comprehensive legislation relating to prevention, abatement and control of pollution and the enhancement of the environment is the Environmental Quality Act 1974 (EQA). The licensing authority under the Act is the Director General of the Department of Environment (DOE). DOE has established several offices in states to manage the environmental issues more effectively. 
Am. J. Applied Sci., 9 (1): 24-31, 2012

Table 2: Legislation in environmental management

\begin{tabular}{lll}
\hline Territory & Act & Implementing agencies \\
\hline Federal laws & Fisheries Act, 1963 (Revised 1978) & Fisheries department \\
& Drainage Works Ordinance, 1(Revised 1972) & Luthority \\
& Street, Drainage and Building Act, (1974) & Local Authority \\
& Local Government Act, (1976) & \\
& National Forestry Act (1984) & Forestry Department \\
Wtate laws & Water Enactment (F.M.S. Chapter 146) 1920 & \\
& (Applicable for all states & \\
& except Kelantan Sabah and Sarawak) & Land Office, DID in advisory capacity \\
& Rivers and Drainage Enactment (Kelantan) & DID \\
Selangor Water Resources Enactment (1999) & LUAS \\
& Environmental Quality (Licensing) Regulations (1977) & DOE \\
& Environmental Quality (Sewage and Industrial Effluents) & \\
& Regulation 1979 Environmental Quality (Scheduled Wastes) & \\
EIA guidelines & Regulations 1989 & \\
& Groundwater and/or Surface Water Supply, (1995) & DID \\
& Drainage and/or Irrigation Projects, 1995 Dams and/or & \\
RID: Department of Irrigation and Drainage; DOE: Department of Environment &
\end{tabular}

DID: Department of Irrigation and Drainage; DOE: Department of Environment

The EQA 1974 specifies that the Minister after consultation with Environmental Quality Council may specify the 'acceptable condition' for the emission or discharge of wastes into any area of environment and may 'prescribe premises the occupation or use of which by any person shall, unless he is the holder of a license issued in respect of those premises, be an offence under the Act." The Act also requires all prescribed premises to be licensed. Traditionally, this covers rubber factories, scheduled waste treatment, disposal facilities and crude palm oil processing facilities. There is also restriction on pollution of inland water which prohibits any discharge of any waste unless licensed into inland water, river, drains or lakes. The proper treatment and discharge of industrial effluent has to be addressed. Environmental Impact Assessment (EIA) has to carry out as part of the project planning exercise for prescribed activities.

Other legislations pertaining to water management include the Street, Drainage and Building Act 1974, which provides powers to local authorities for the control, construction and management of sewerage works and drainage within local authority areas. The Local Government Act 1976, which has the power to take all necessary and practical means to promote and preserve public health. The National Forestry Act 1984 provides for the protection of the forests, which includes preservation of water catchments and rivers. The Selangor Water Resources Enactment 1999 provides for the management and the protection of the basins, water recourses in any designated area including catchments areas and river basins within the state Selangor. Regulations regarding water also may come from ministerial directives and cabinets decisions, which are provided for in the Ministerial Functions Act 1969.
Inter-agency coordination in river water management: Rivers contribute $97 \%$ of our fresh water resource, it the biggest source of water for potable water supply and irrigation (Kalithasan, 2007). Rivers are also the habitats for riverine and aquatic flora and fauna and the river environment supports a rich biodiversity of life forms (Weng, 2003). Water is an essential necessity of human existence and industrial development and it is one the most delicate component of the environment (Das and Acharya, 2003; Amadi et al., 2010; Suwandana et al., 2011). These facts are sufficient to give us a wake-up call on the importance of rivers to the sustainability of life on earth and thus the need for humans to ensure the rivers are always kept clean for present and future use. An effective management of water resources requires full participation from the various stakeholders and carried out in a holistic approach. River pollution involves various cross-cutting interrelated issues that warrants for effective control and management of river pollution. The study shows that there is a lack of inter-agency coordination in the management of river pollution. At present, river pollution issues are managed on sectoral basis-that frequently give rise to numerous bureaucratic sluggishness and departmental rivalry.

Given that river management issues are both multifaceted and interconnected, there is greater realization on the need to institute comprehensive river water management system. Since there are various stakeholders and agencies involved in water management, coordination between them has appeared be rather problematic-which eventually led to poor management of rivers, especially in urban areas. Water activities such as watershed management, water resources development and management, navigation, fisheries and mining are placed in the State's list. 
Am. J. Applied Sci., 9 (1): 24-31, 2012

Despite the comprehensive legislations at state level, such as the Water Authority Management Enactment in Selangor, there is still lack of recognition on the role of local communities into water resources planning and management. For better coordination among waterrelated agencies, the Ministry of Natural Resources (NRE) was established in 2004, combining departments from four other ministries-to ensure better integration of water resources management. While such initiative appears good on study, the management of water resources is still shared by other ministries such as water services monitoring and supervision (Ministry of Water, Energy and Communication); monitoring and safeguarding of water resources and natural resources (Ministry of Natural Resources and Environment); water research and development (Ministry Science, Technology and Innovation), drinking water quality (Ministry of Health), water planning and development (Local Governments). Although the ministry changed its name to Ministry of Energy, Green Technology and Water from 9 April 2009, water management efforts are still largely segregated between several agencies.

The lack of inter-agency coordination also manifests in the scope of jurisdiction among agencies responsible for natural resources management. For instance, Department of Environment (DOE), which executes the Environmental Quality Assessment (EQA) 1974 is responsible for industrial pollution control. The other natural resource sectors like forestry, fisheries, mining and agriculture come under the jurisdiction of other ministries, with split sets of regulatory laws. Each ministry places more weightage in promoting polices that they are entrusted with, within their own jurisdictions. However, such actions are carried out without necessary coordination with related agenciesactions that possibly more damaging to the environment. In another words, ministries appear to be overly protective of their powers and jurisdiction of responsibilities. In the case of DOE, it appraises the Environmental Impact Assessment (EIA) report for land development projects and makes recommendations as to whether the development is to be permitted or refused. A planning authority may consult any authority, department, person or body before determining an application for planning permission. Nevertheless, it is not obligatory for the planning authority to strictly follow the recommendations by authorities providing advisory decisions. The planning authority can disregard the recommendations of DOE and other government agencies. The Town and Country Planning Act 1976 provides that in determining planning applications, the planning authorities are required to take into consideration all aspects necessary for proper planning, including the directives given by the State Planning Committee. The State Planning Committee may ask for the approval of an application for planning permission to be considered for the purposes of economic development even if such projects overlap with the policies in the development plans.

Pollution mitigation and water quality improvement are largely dependent on the efforts of several inter-related agencies. Therefore it is critical to ensure the successful implementation of any proposed reforms in river management. There were cases where agencies were given specific tasks and responsibility with regard to water management but had to depend on other agencies to enforce the relevant laws. Such situation demands close cooperation with the agencies concerned-but it most cases it is hampered by different priorities and responsibilities. For example, local government authorities have relied on the advice of the Department of Irrigation and Drainage (DID) for land development control and technical matters. DID often undertakes initiative to prepare drainage master-plans on behalf of the local government authorities as these authorities, in many cases, do not have sufficient budget. Besides that, due to its better financial situation and technical expertise, DID also undertakes the responsibility of the development of some trunk drains. Presently, there is no clear demarcation of responsibilities between local government authorities and DID with regards to such matters.

Federal-states politics also play an important role in the mismanagement of water resources, especially the rivers. In has been observed that political influences hamper the enforcement of laws regarding rivers. In spite of comprehensive laws regarding water resources, enforcement still persist to be a persistent problem. Given that several states in Malaysia are governed by political parties different from the Federal government, water matters something becomes heated political issue. This situation is further worsened by overlapping functions and enforcements mechanism between these agencies. Although many departments and waterrelated agencies have specific jurisdictions over river basins, many do not have legal backing for preventive and punitive actions against water offenders. The study shows that effective enforcement and pollution management of water resources are largely dependent on cooperation and coordination between water authorities at various levels of government, which seems to be lacking due to legislations and political issues. In addition, feedback from the interviews suggests that water managers are less aware of water ethics and how such principles can play a role in the management of water resources of the country. In fact, 
many of the respondents had shown tendencies to approach water issues from a technical perspective. They were less cognizant to the socioeconomic and social justice perspectives of river water management.

\section{CONCLUSION}

The study concludes that the National Water Policy provides a holistic coverage on matters of water to include aspects of water for human survivability, food and rural development, economic development and environmental protection. However in the realization of its objectives, there are several problems and issues that need to be addressed. In has been cited in this study that the issues regarding federal-states jurisdictions, the overlaps and grey-areas in the role and functions of water management agencies and issues regarding legislations and enforcement are barriers of the achievement of the policy's objectives. This study is of the view that, besides the need for structured coordination between these agencies and in water legislations, it is vital to instill the knowledge of "water ethics' in the policy formulation and implementation initiatives-being cognizant of the fundamentals of human dignity, society participation and responsibility, equality, common good, stewardship and other ethical precepts that will assist in the preservation of water resources and its dependent ecosystems.

\section{REFERENCES}

Amadi, A.N., P.I. Olasehinde, E.A. Okosun and J. Yisa, 2010. Assessment of the water quality index of otamiri and oramiriukwa rivers. Phys. Int., 1: 102109. DOI: $10.3844 /$ pisp.2010.116.123

Das, J. and B.C. Acharya, 2003. Hydrology and assessment of lotic water quality in Cuttack city, India. Water Air Soil Pollut., 150: 163-175. DOI: 10.1023/A: 1026193514875

Gandaseca, S., N. Rosli, J. Ngayop and C.I. Arianto, 2011. Status of water quality based on the physicochemical assessment on river water at wildlife sanctuary sibuti mangrove forest, miri Sarawak. Am. J. Environ. Sci., 7: 269-275. DOI: 10.3844/ajessp.2011.269.275
Kalithasan, K., 2007. Community Water Quality Monitoring Programme in Malaysia. Paper presented at the WEPA International Forum, Bangkok.

Lee, K.Y., 2004. What is Water Policy and What is its Purpose. Buletin Ingenieur., 22: 44-46.

Macer, D.R.J., 2008. Moral Games for Teaching Bioethics. 1st Edn., UNESCO Chair in Bioethics, Israel, ISBN: 9657077400, pp: 122.

Moorthy, R. and G. Jeyabalan, 2011. Environmental ethics in river water management. Am. J. Environ. Sci., 7 : 370-376. DOI: 10.3844/ajessp.2011.370.376

Moorthy, R. and S. Sivapalan, 2010. Some ethical thoughts from the Indian traditions. Eubios, J. Asian, Int. Bioethics, 20: 180-183.

Refsgaard, J.C., 2002. State-of-the-art report on quality assurance in modelling related to river basin management. HarmoniQuA Report D-WP1-1, Copenhagen, Denmark.

Shahabudin, S.M., 2005. Restructuring Water Services in Malaysia. Buletin Ingenieur., 28: 8-11. ISSN 0128-4347.

Suwandana, E., K. Kawamura, K. Tanaka, Y. Sakuno and P. Raharjo, 2011. Escherichia coli and biophysicochemical relationships of seawater and water pollution index in the Jakarta bay. Am. J. Environ. Sci., 7: 183-194. DOI: 10.3844/ajessp.2011.183.194

Ti, L.H. and T. Facon, 2001. From Vision to Action: A Synthesis of Experiences in Southeast Asia. 1st Edn., FAO/ESCAP, Bangkok, pp: 121.

Weng, C.N., 2003. Water Resources Management in Malaysia: NGO Perspectives.

Yew, L.K., 2004. What is water policy and what is its purpose. Buletin Ingenieur., 22: 44-46. 